\title{
Qualitative properties of cookies enriched with berries pomace
}

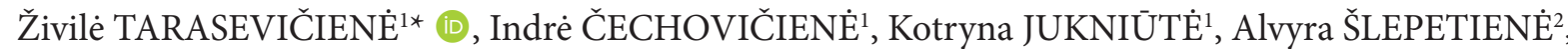 \\ Aurelija PAULAUSKIENE ${ }^{1}$
}

\begin{abstract}
The purpose of this study was to investigate the qualitative properties of cookies with the addition of raspberry, red currants and strawberry pomace flour. Cookies were prepared by substitution of wheat flour with berry pomace flour $(10 \%, 15 \%$ and $20 \%)$ and evaluated in terms of their proximate composition, physical characteristics, and functional and sensory properties. Berry pomace-supplemented cookies had significantly higher dietary fibre content and different fibre fractions NDF (neutral detergent fibre), ADF (acid detergent fibre), MADF (insoluble fibre fraction of modified acid detergent solution) as well as WSCs (water soluble carbohydrates) content. Correlation analysis results showed that cookie hardness was significantly correlated with dietary fibre content. The raspberry, red currant and strawberry flours contained $49.88 \%, 33.13 \%$ and $24.25 \%$ of dietary fibre, respectively. The colour of the cookies was measured using a Color Flex spectrophotometer. The average $\mathrm{L}^{*}, \mathrm{a}^{*}$, and $\mathrm{b}^{*}$ values ranged from 37.35 to 68.29 , from 7.08 to 13.18 , and from 20.12 to 34.73 , respectively.
\end{abstract}

Keywords: by-product; functional ingredient; cookies; fiber; pomace.

Practical Application: Enrich wheat cookies with natural dietary fibre from berry pomace flour.

\section{Introduction}

In recent years, there has been a rising interest in functional food, especially when enriched with bioactive substances. Among many bioactive substances to be found in food - such as antioxidants, plant sterols, pro and prebiotics and vitamins - a crucial role is played by dietary fibre (Rodríguez et al., 2006). By-products can be described as the waste after the processing of fruit- and vegetable-based products, and these remnants include peels, pips, skins, stems and cores (Brodowska, 2017). The food industry produces significant amounts of by-products, which become problematic in their disposal. Usually, these products are used in animal feeding (Leroy et al., 2007; Górecka et al., 2010; Angulo et al., 2012). However, research has shown that by-products can also have a high nutritional value (O'Shea et al., 2012).

Berries are rich sources of dietary antioxidants and other bioactive compounds (flavonols, phenolic acids, ellagitannins, vitamins $\mathrm{C}$ and $\mathrm{E}$, folic acid and $\beta$-sitosterol). Many of these bioactive compounds exhibit antioxidant activity (Kostecka-Gugała et al., 2015). Pressing of berry juice results in high amounts of residues, which are called press-cake, pomace or marc. If such residues are not processed into other products, they are considered waste (Kryževičiūtè et al., 2016). Pomace contains many valuable ingredients such as carbohydrates, proteins, fats, vitamins, pectins and fibres (Djilas et al., 2009). Dietary fibre is not only used for its nutritional properties but also for its functional and technological properties. Novel sources of fibre have been discovered and utilized. One of these sources is the by-product fraction from different types of food processing. In particular, the by-products obtained from fruit and vegetable processing (e.g., juices, drinks) are gaining attention as novel and economic sources of a healthy functional ingredient (Ayala-Zavala et al., 2011). The high content of dietary fibre could permit their usage in food products (Górecka et al., 2010). The type of fibre eaten has a direct influence on the human digestive tract; it lowers the glucose level in blood, binds bile acid and lowers the level of cholesterol (Górecka et al., 2002). Dietary fibre has received much positive attention with regard to its potential as a pharmafood due to its ability to reduce cholesterol, diabetes and coronary heart disease and ease constipation (Telrandhe et al., 2012).

The main ingredient in traditional cookies consists of foods rich in carbohydrates and therefore lacking in essential nutritional components such as dietary fibre, vitamins and minerals, with very low levels of wheat flour. One of the potential ways to reduce the glycaemic index of products is the partial replacement of wheat flour with berry pomace flour. Pomace is a good phytochemical source for food enrichment (Naknaen et al., 2016).

The aim of this study was to evaluate the possibilities of enriching confectionery products with berry pomace dietary fibre without impairing the sensory qualities.

\section{Materials and methods}

\subsection{Materials}

Wheat flour (550 C type), sodium bicarbonate, salt, skimmed milk powder, butter ( $82 \%$ fat) and sugar were obtained from local supermarkets (Kaunas, Lithuania). All the chemicals used in the food analysis were of analytical grade. 


\subsection{Plant material}

Freshly pressed pomace of strawberry, red currant and raspberry was obtained from a local juice industry in Kaunas county, Lithuania. The pomace was dried in a hot-air drying convection oven (Model SLN 240, Wodzisław Śląski, Poland) at $50{ }^{\circ} \mathrm{C}$ for 24 hours, and grinded with a food mill (Model Retsch ZM200, Haan, Germany) to flour consistency (0.2 mm particle size).

\subsection{Preparation of cookies}

Cookies were prepared using the standard AACC method (American Association of Cereal Chemists, 2000). For the production of cookie dough, the ingredients used were the highest quality wheat $550 \mathrm{C}$ type flour $(100 \mathrm{~g})$, sodium bicarbonate $(1.0 \mathrm{~g})$, salt (1.0 g), skimmed milk powder $(20 \mathrm{~g})$, butter $(50 \mathrm{~g})$, sugar $(40 \mathrm{~g})$ and water $(20 \mathrm{~mL})$. The butter was mixed with sugar until it reached a creamy consistency and then mixed with the flour, sodium bicarbonate, salt, skimmed milk powder and formed dough. The same procedure was used for the cookies with pomace supplement, except the wheat flour was replaced with $10 \%, 15 \%$ and $20 \%$ of berry pomace flour. The dough was rolled to a uniform thickness of $0.5 \mathrm{~cm}$ and cut into rectangles ( $2 \mathrm{~cm}$ wide and $7 \mathrm{~cm}$ long). The cookies were baked at $180{ }^{\circ} \mathrm{C}$ for 10 minutes, then cooled and kept in hermetic bags until the analyses.

\subsection{Proximate composition}

Wheat and pomace flour were analysed according to the international standards for its dry matter (International Organization for Standardization, 1998), ash (International Organization for Standardization, 2002), protein (International Organization for Standardization, 2013), fat (International Organization for Standardization, 2015a) and total fibre content (International Organization for Standardization, 2008) and expressed as the mass percentage of dry matter. Cookies with berry pomace supplements were analysed according to the same international standards as wheat and berry pomace flour (International Organization for Standardization, 1998, 2002, 2008, 2013, 2015a).

\subsection{Measurement of $\mathrm{pH}$}

Pomace flour $(0.4 \mathrm{~g})$ was mixed with $20 \mathrm{~mL}$ of deionised water and vortexed for $3 \mathrm{~min}$. The mixture was held at $21{ }^{\circ} \mathrm{C}$ for $1 \mathrm{~h}$. After centrifugation, the $\mathrm{pH}$ was measured using a $\mathrm{pH}$ meter (MeterLab PHM210, France). Cookies with berry pomace supplements were analysed according to the same method (Žilić et al., 2016).

\subsection{Determination of dietary fiber fraction}

Cookie samples were analysed for acid detergent fibre (ADF: cellulose and lignin) and neutral detergent fibre (NDF: cellulose, hemicellulose and lignin) using the fractionation method as specified by Faithfull (2002). ADF extraction was performed with an ANKOM220 Fibre Analyser (ANKOM Technology Method 08-16-06) using F57 filter bags $(25 \mu \mathrm{m})$. Currently, the most widely used fibre fractionation system is the Van Soest analysis method by Van Soest et al. (1991). NDF was analysed using sodium sulphite, and the results are presented as ash-free. The MADF was determined using the gravimetric method by washing in a modified solution of sulphuric acid and cetyltrimethylammonium bromide (CTAB) (Methodenbuch - VDLUFA, 1983-1999). The concentration of madf (WSCs) in the water extracts of the dried samples was measured photocolorimetrically using the anthrone reagent (Yemm \& Willis, 1954; Butkutè et al., 2013).

\subsection{Color of dough and cookies}

The colour was detected by the Color Flex spectrophotometer (Hunter Associates Laboratory Inc, USA) and recorded in $\mathrm{L}^{*}$, $\mathrm{a}^{\star}$, and $\mathrm{b}^{\star} \mathrm{CIE}$ coordinates. The $\mathrm{L}^{*}$ (lightness) value ranges from $0=$ black to $100=$ white, the $\mathrm{a}^{\star}$ (redness) ranges from green (negative) to red (positive), and $\mathrm{b}^{\star}$ (yellowness) values are blue (negative) to yellow (positive). The chroma meter was calibrated with a standard white reflective plate (Žilić et al., 2016).

\subsection{Texture of dough and cookies}

Texture profile analysis (TPA) of the dough and cookie samples was carried out by the texture analyser TA. XT plus (Stable Micro Systems, England) equipped with a P20 adapter moving at a rate of $2 \mathrm{~mm} / \mathrm{s}$, and the penetration depth into the dough and cookie samples was $8 \mathrm{~mm}$. The hardness $(\mathrm{N})$, maximum force opposed to fracture, and brittleness ( $\mathrm{mm}$ ) was determined (Zucco et al., 2011).

\subsection{Sensory evaluation of cookies}

The sensory evaluation of the cookies was performed according to the method reported by Peryam \& Pilgrim (1957). The colour, aroma, texture and taste of the cookie samples were evaluated by a 9 point hedonic scale, where $1=$ extremely dislike, $5=$ neither like nor dislike and $9=$ extremely like. The samples were identified by code numbers and presented in random order to the panellists (Mudgil et al., 2017).

\subsection{Statistical analysis}

The results of the research were statistically evaluated by one-way analysis of variance method (ANOVA) using Fisher's test with a $\mathrm{p}<0.05$ significance level, using the STATISTICA computer programme. The relationship between measured parameters was assessed by Pearson's linear correlation test at a $\mathrm{p}<0.05$ significance level.

\section{Results and discussion}

\subsection{Flour analysis}

The wheat flour used for this study contained $87.00 \%$ dry matter, $0.56 \%$ ash, $9.15 \%$ protein, $1.67 \%$ fat and $0.56 \%$ fibre.

The amount of dry matter in the berry pomace flours was lowest in the strawberry pomace flour $(88.97 \%)$ and highest in the raspberry pomace flour $(91.49 \%)$. This dry matter content in raspberry pomace is consistent with that reported by Fotschki et al. (2019) (93.13\%). 
The accumulated ash content was highest in red currant pomace $(3.77 \%)$ and lowest in raspberry pomace flour $(2.31 \%)$. Other researchers have reported similar ash content in raspberry pomace (2.2\%) (McDougall \& Beames, 1994). Kosmala et al. (2014) reported that ash content in strawberry pomace was $8 \%$, of which $6 \%$ was sand.

Comparing protein content in the different berry pomace flours demonstrated no statistically significant differences. Protein content ranged from $6.85 \%$ in red currant to $6.38 \%$ in raspberry pomace. Earlier research by McDougall \& Beames (1994) reported the amount of protein in raspberry pomace to be $10 \%$. Fotschki et al. (2019) reported higher protein content in raspberry pomace (11.20\%). Kosmala et al. (2014) found $21 \%$ of the protein in the seedling strawberry pomace. Tagliani et al., (2019) found $6.64 \%$ of protein in blueberry pomace powder.

The highest amount of fat was found in raspberry pomace (11.09\%) and the lowest in red currant pomace flour (3.58\%). McDougall \& Beames (1994) reported 11.1\% fat content in raspberry pomace, and according to Kosmala et al. (2014), strawberry pomace contained $5.5 \%$, and according Tagliani et al. (2019), blueberry pomace powder contained $4.05 \%$ fat.

Fibre content differed significantly in the three types of berry pomace examined. The largest difference in fibre content was detected between raspberry and strawberry pomace flours (25.63 percentage units) (Table 1). Fotschki et al. (2019) reported $64.76 \%$ dietary fibre in raspberry pomace. Blackcurrant and strawberry pomace can contain high amounts of dietary fibre exceeding 50\% of the dry weight (Jurgonski et al., 2016).

Significantly, the highest amount of neutral detergent fibre (NDF), acid detergent fibre (ADF) and insoluble fibre fraction of modified acid detergent solution (MADF) were found in raspberry pomace and the lowest in strawberry pomace. The highest amount of water soluble carbohydrates (WSCs) was found in strawberry pomace $(33.30 \%)$ and the lowest in raspberry pomace (14.40\%). Red currant pomace had the highest content of MADF (63.85\%), and raspberry and strawberry pomaces had the highest NDF content $(68.20 \%$ and $38.90 \%$, respectively). The content of WSCs and MADF only differed significantly between the raspberry and strawberry and the red currant and strawberry pomace flours. Significant differences in NDF and ADF fibre fraction contents were identified in all the berry pomace flours (Table 2). According to the literature, raspberry pomace dry matter can contain 54.9\% NDF, $2.5 \%$ WSCs and 75.0\% MADF (Górecka et al., 2010).

The red currant pomace was determined the most acidic (3.33 $\mathrm{pH})$, and the least acidic was wheat flour $(5.72 \mathrm{pH})$. Comparing the $\mathrm{pH}$ of the berry pomace flours, the least acidic was strawberry pomace flour (3.86\%). All berry pomace flours were acidic (Figure 1).

\subsection{Cookies analysis}

The highest content of dry matter (93.01\%) was found in cookies with $20 \%$ raspberry pomace flour additive and the lowest (90.44\%) in cookies with $10 \%$ strawberry pomace flour. Low moisture content can impact the stability of the cookies and is expected to enhance their shelf-life. High moisture content produces a delay in the Maillard reaction and caramelisation (Verdú et al., 2019).

The highest content of crude ash (3.85\%) was observed in cookies with $20 \%$ red currant pomace flour and the lowest

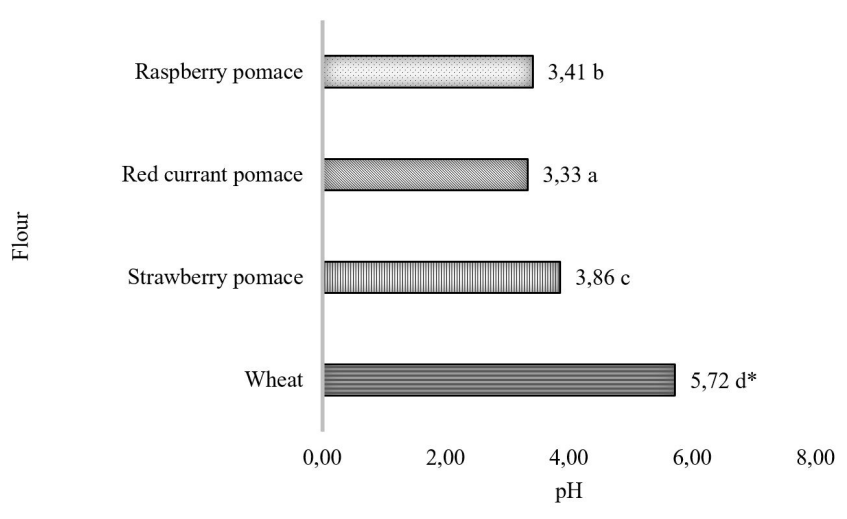

Figure 1. Wheat and berry pomace flour $\mathrm{pH}$. Different letters above the column indicate significant differences between the mean values ( $\mathrm{p} \leq 0.05^{*}$ compared to control).

Table 1. Chemical content of wheat and berry pomace flour, \% in dry matter.

\begin{tabular}{lcrrrrr}
\hline \multicolumn{1}{c}{ Flour } & Dry matter & \multicolumn{1}{c}{ Ash } & Protein & \multicolumn{1}{c}{ Fat } & Fiber & $\begin{array}{c}\text { Nitrogen free } \\
\text { extractives }\end{array}$ \\
\hline Wheat & $87.00 \pm 1.2 \mathrm{a}$ & $0.56 \pm 0.4 \mathrm{a}$ & $9.15 \pm 0.8 \mathrm{~b}$ & $1.67 \pm 0.3 \mathrm{a}$ & $0.56 \pm 0.1 \mathrm{a}$ & $75.06 \pm 0.9 \mathrm{a}$ \\
Raspberry pomace & $91.49 \pm 0.9 \mathrm{c}$ & $2.31 \pm 0.3 \mathrm{~b}$ & $6.38 \pm 0.5 \mathrm{a}$ & $11.09 \pm 0.5 \mathrm{~d}$ & $49.88 \pm 1.4 \mathrm{~d}$ & $21.83 \pm 0.5 \mathrm{~b}$ \\
Red currant pomace & $91.20 \pm 1.0 \mathrm{c}$ & $3.77 \pm 0.6 \mathrm{~d}$ & $6.85 \pm 0.4 \mathrm{a}$ & $3.58 \pm 0.2 \mathrm{~b}$ & $33.13 \pm 1.2 \mathrm{c}$ & $43.87 \pm 0.8 \mathrm{c}$ \\
Strawberry pomace & $88.97 \pm 1.3 \mathrm{~b}$ & $3.1 \pm 0.3 \mathrm{c}$ & $6.65 \pm 0.4 \mathrm{a}$ & $7.46 \pm 0.4 \mathrm{c}$ & $24.25 \pm 1.1 \mathrm{~b}$ & $47.51 \pm 0.7 \mathrm{c}$ \\
\hline
\end{tabular}

Different letters above the column indicate significant differences between the mean values $(\mathrm{p} \leq 0.05)$ (Mean \pm SD).

Table 2. The content of dietary fiber fractions and water soluble carbohydrates in berry pomace, $\%$ in dry matter.

\begin{tabular}{lcccc}
\hline Berry pomace flour & NDF & ADF & MADF & WSCs \\
\hline Raspberry & $68.20 \pm 1.3 \mathrm{c}$ & $64.65 \pm 1.3 \mathrm{c}$ & $65.90 \pm 1.2 \mathrm{a}$ & $14.40 \pm 0.3 \mathrm{a}$ \\
Red currant & $59.25 \pm 1.2 \mathrm{~b}$ & $58.75 \pm 1.1 \mathrm{~b}$ & $63.85 \pm 1.3 \mathrm{a}$ & $16.00 \pm 0.4 \mathrm{a}$ \\
Strawberry & $38.90 \pm 0.8 \mathrm{a}$ & $37.95 \pm 0.7 \mathrm{a}$ & $37.95 \pm 0.8 \mathrm{~b}$ & $33.30 \pm 0.9 \mathrm{~b}$ \\
\hline
\end{tabular}

Different letters above the column indicate significant differences between the mean values $(\mathrm{p} \leq 0.05)(\mathrm{Mean} \pm \mathrm{SD})$. Neutral detergent fibre (NDF), acid detergent fibre (ADF) and insoluble fibre fraction of modified acid detergent solution (MADF), water soluble carbohydrates (WSCs). 
(1.56\%) in the wheat flour cookies. Brites et al. (2019) reported that content of crude ash in wheat flour cookies is $0.51 \%$.

The highest amount of protein was found in the wheat flour cookies $(9.41 \%)$, and the lowest $(8.81 \%)$ in cookies with $10 \%$ raspberry pomace flour.

The maximum content of fat $(20.74 \%)$ was found in the cookies with $20 \%$ raspberry pomace flour and the lowest $(19.16 \%)$ in the cookies with $10 \%$ red currant pomace flour.

Cookies with $20 \%$ raspberry pomace flour contained the highest fibre content (15.66\%), and among the berry pomace flours, red currant pomace cookies with $10 \%$ additive contained the least fibre (10.61\%) (Table 3).

The cookies with $20 \%$ red currant pomace flour were the most acidic ones $(5.53 \mathrm{pH})$, while the least acidic were those with $10 \%$ raspberry pomace flour $(6.83 \mathrm{pH})$. By increasing the additive of all the berry pomace flours, the acidity of the cookies also increased. Wheat flour cookies were the least acidified (Figure 2).

It can be stated that water soluble carbohydrates (WSCs) were predominantly determined in all the cookie types. The results ranged from an average of $24.30 \%$ (wheat flour cookies) to $29.25 \%$ (cookies with $20 \%$ strawberry pomace flour supplement). When comparing the fibre fractions, most of the fibre was in the

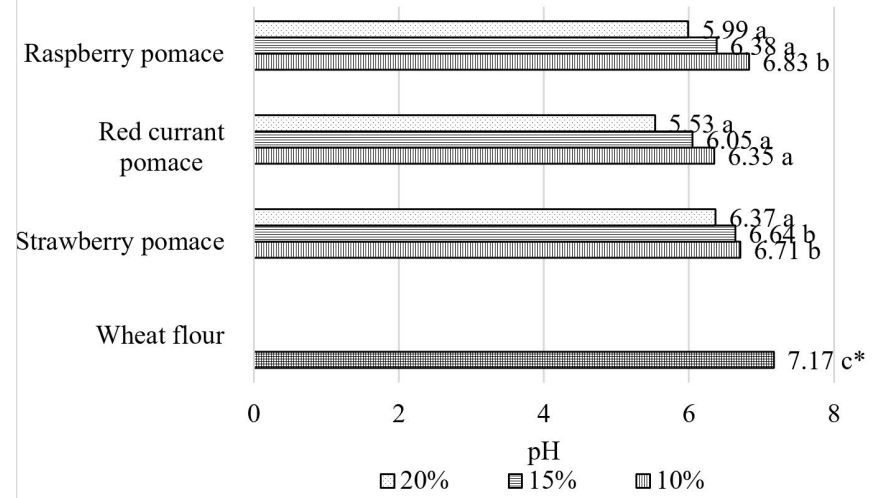

Figure 2. Cookies with berry pomace flour $\mathrm{pH}$. Different letters above the column indicate significant differences between the mean values ( $\mathrm{p} \leq 0.05{ }^{*}$ compared to control). cookies with $20 \%$ raspberry pomace additive, with $17.3 \%$ NDF, 16.15\% ADF and 18.80\% MADF (Table 4). D. Górecka et al. (2010) reported that, in cookies with $25 \%$ raspberry pomace

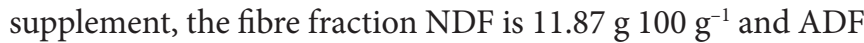

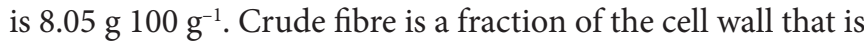
not broken by strong acids and alkalis. It consists of a portion of lignin and cellulose. This procedure determines two fibre fractions: washed-in-acid solution ADF, consisting of cellulose, lignin, heat-degraded (denatured) protein and ash insoluble in acids, and NDF, washed in neutral solution, containing all the cell wall structural material. Often, the ADF is replaced by another form, MADF, the leached fibre in the modified acid solution. The amount of fibre remaining after such leaching is widely used to calculate digestibility and metabolic energy (Jones \& Moseley, 1993).

Food colour influences consumer behaviour - including choice priorities - and therefore has economic value. With increasing consumer awareness, a healthy lifestyle requires a growing demand for natural dyes from fruits, vegetables, herbs and spices, rather than synthetic ones. For example, raspberry pomace is a source of anthocyanins and carotenoids (Brodowska, 2017). The cookie colour is an important factor for the initial acceptability of food products by consumers (Chauhan et al., 2016).

The brightness coordinate $\mathrm{L}^{\star}$ showed that the dough without berry pomace flour was the brightest (72.92 NBS). When comparing the types of pomace flour dough, the lightest dough was the one with $10 \%$ red currant pomace flour (54.69 NBS), and the lowest value (35.72) was for the $20 \%$ strawberry pomace flour cookie dough. Evaluating the $a^{\star}$ value for red colour, it was determined that higher amounts of pomace yielded a more intense red colour in the pastry. Assessing the $b^{\star}$ value for yellow colour revealed that lower pomace content yielded a more intense yellow colour in the pastry (Table 5).

Regarding the intensity of the colour, the darkest cookies were observed with $20 \%$ strawberry pomace, and the more reddish with $15 \%$ raspberry pomace flour (Table 6 ). This could be due to the higher content of reducing sugars in strawberry pomace flours that could impart a darker colour to the products (Sanchez-Rivera et al., 2019).

Table 3. Amount of dry matter and chemical content of wheat and berry pomace flour cookies, \% in dry matter.

\begin{tabular}{|c|c|c|c|c|c|c|c|}
\hline Flour & & Dry matter & Ash & Protein & Fat & Fiber & $\begin{array}{c}\text { Nitrogen free } \\
\text { extractives }\end{array}$ \\
\hline Wheat & & $92.33 \pm 1.3 \mathrm{c}$ & $1.56 \pm 0.1 \mathrm{a}$ & $9.41 \pm 0.4 \mathrm{c}$ & $20.50 \pm 0.7 \mathrm{~d}$ & $7.4 \pm 0.4 \mathrm{a}$ & $61.13 \pm 1.1 \mathrm{c}$ \\
\hline \multirow{3}{*}{ Raspberry pomace } & $10 \%$ & $91.21 \pm 1.2 \mathrm{~b}$ & $2.66 \pm 0.3 \mathrm{c}$ & $8.81 \pm 0.3 b$ & $19.30 \pm 0.4 \mathrm{a}$ & $13.84 \pm 0.6 \mathrm{c}$ & $55.39 \pm 0.9 \mathrm{~b}$ \\
\hline & $15 \%$ & $92.55 \pm 1.2 \mathrm{c}$ & $3.01 \pm 0.2 c$ & $8.86 \pm 0.3 b$ & $20.26 \pm 0.3 b$ & $13.98 \pm 0.4 \mathrm{c}$ & $53.89 \pm 0.8 \mathrm{a}$ \\
\hline & $20 \%$ & $93.01 \pm 1.4 \mathrm{c}$ & $3.12 \pm 0.4 \mathrm{c}$ & $9.01 \pm 0.2 \mathrm{c}$ & $20.74 \pm 0.4 c$ & $15.66 \pm 0.7 c$ & $51.47 \pm 0.9 \mathrm{a}$ \\
\hline \multirow[t]{3}{*}{ Red currant pomace } & $10 \%$ & $91.04 \pm 1.0 \mathrm{~b}$ & $2.01 \pm 0.2 \mathrm{~b}$ & $8.88 \pm 0.2 \mathrm{~b}$ & $19.16 \pm 0.4 \mathrm{a}$ & $10.61 \pm 0.4 b$ & $59.34 \pm 0.8 \mathrm{c}$ \\
\hline & $15 \%$ & $91.21 \pm 1.1 \mathrm{~b}$ & $2.67 \pm 0.1 \mathrm{c}$ & $8.91 \pm 0.1 \mathrm{~b}$ & $19.78 \pm 0.2 b$ & $13.13 \pm 0.4 b$ & $55.51 \pm 0.7 \mathrm{~b}$ \\
\hline & $20 \%$ & $92.14 \pm 1.3 \mathrm{c}$ & $3.85 \pm 0.4 \mathrm{~d}$ & $8.94 \pm 0.1 \mathrm{a}$ & $20.48 \pm 0.4 c$ & $13.23 \pm 0.3 b$ & $53.50 \pm 0.7 \mathrm{a}$ \\
\hline \multirow[t]{3}{*}{ Strawberry pomace } & $10 \%$ & $90.44 \pm 1.2 \mathrm{a}$ & $2.45 \pm 0.2 \mathrm{c}$ & $8.84 \pm 0.1 b$ & $20.01 \pm 0.4 b$ & $10.83 \pm 0.2 b$ & $57.87 \pm 0.6 \mathrm{~b}$ \\
\hline & $15 \%$ & $90.94 \pm 1.4 \mathrm{~b}$ & $2.81 \pm 0.2 \mathrm{c}$ & $8.90 \pm 0.2 b$ & $20.40 \pm 0.3 b$ & $11.61 \pm 0.4 b$ & $56.28 \pm 0.8 \mathrm{~b}$ \\
\hline & $20 \%$ & $92.20 \pm 1.1 \mathrm{c}$ & $2.86 \pm 0.2 \mathrm{c}$ & $9.05 \pm 0.3 c$ & $20.56 \pm 0.4 \mathrm{c}$ & $12.20 \pm 0.4 \mathrm{~b}$ & $55.33 \pm 0.8 \mathrm{~b}$ \\
\hline
\end{tabular}

Different letters above the column indicate significant differences between the mean values $(\mathrm{p} \leq 0.05)(\mathrm{Mean} \pm \mathrm{SD})$. 
Table 4. The content of dietary fiber fractions in cookies with addition of berry pomace, \% in dry matter.

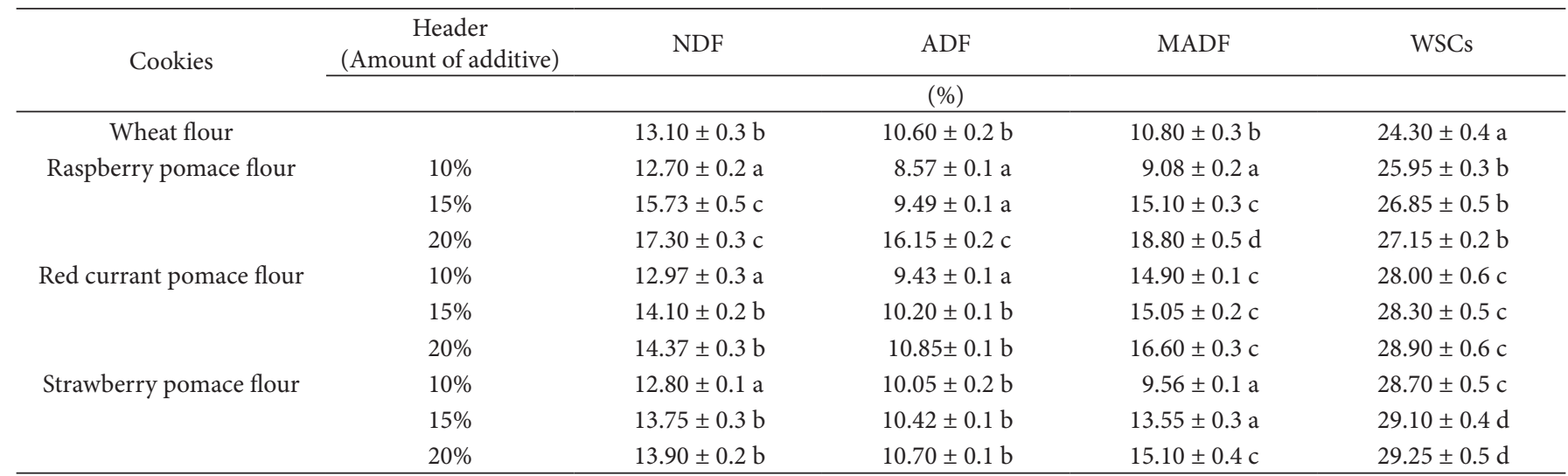

Different letters above the column indicate significant differences between the mean values ( $\mathrm{p} \leq 0.05)$ (Mean \pm SD). Neutral detergent fibre (NDF), acid detergent fibre (ADF) and insoluble fibre fraction of modified acid detergent solution (MADF), water soluble carbohydrates (WSCs).

Table 5. The color of cookies dough with addition of berry pomace flour.

\begin{tabular}{|c|c|c|c|c|}
\hline \multirow{2}{*}{ Cookies dough } & \multirow{2}{*}{$\begin{array}{c}\text { Header } \\
\text { (Amount of additive) }\end{array}$} & $\mathrm{L}^{*}$ & $a^{*}$ & $b^{*}$ \\
\hline & & \multicolumn{3}{|c|}{ NBS units } \\
\hline Wheat flour & & $72.92 \pm 1.4 \mathrm{~g}$ & $4.81 \pm 0.1 \mathrm{a}$ & $32.46 \pm 0.7 \mathrm{~g}$ \\
\hline \multirow[t]{3}{*}{ Raspberry pomace flour } & $10 \%$ & $41.82 \pm 0.9 c$ & $8.44 \pm 0.3 b$ & $12.34 \pm 0.4 \mathrm{~b}$ \\
\hline & $15 \%$ & $37.73 \pm 0.7 \mathrm{~b}$ & $10.99 \pm 0.4 \mathrm{e}$ & $9.66 \pm 0.3 \mathrm{a}$ \\
\hline & $20 \%$ & $41.11 \pm 0.5 \mathrm{c}$ & $9.93 \pm 0.4 c$ & $11.55 \pm 0.2 \mathrm{~b}$ \\
\hline \multirow[t]{3}{*}{ Red currant pomace flour } & $10 \%$ & $54.69 \pm 0.7 \mathrm{f}$ & $10.50 \pm 0.3 \mathrm{~d}$ & $18.20 \pm 0.4 \mathrm{f}$ \\
\hline & $15 \%$ & $49.65 \pm 0.8 \mathrm{e}$ & $12.91 \pm 0.4 \mathrm{f}$ & $17.63 \pm 0.5 \mathrm{f}$ \\
\hline & $20 \%$ & $43.45 \pm 0.6 \mathrm{~d}$ & $13.32 \pm 0.2 \mathrm{f}$ & $15.73 \pm 0.5 \mathrm{~d}$ \\
\hline \multirow[t]{3}{*}{ Strawberry pomace flour } & $10 \%$ & $46.21 \pm 0.8 \mathrm{~b}$ & $9.84 \pm 0.2 c$ & $18.98 \pm 0.6 \mathrm{f}$ \\
\hline & $15 \%$ & $37.46 \pm 0.6 b$ & $10.19 \pm 0.3 \mathrm{~d}$ & $16.72 \pm 0.3 \mathrm{e}$ \\
\hline & $20 \%$ & $35.72 \pm 0.4 \mathrm{a}$ & $10.59 \pm 0.3 \mathrm{~d}$ & $15.12 \pm 0.3 c$ \\
\hline
\end{tabular}

Different letters above the column indicate significant differences between the mean values $(\mathrm{p} \leq 0.05)($ Mean \pm SD).

Table 6. The color of cookies with addition of berry pomace flour.

\begin{tabular}{|c|c|c|c|c|}
\hline \multirow{2}{*}{ Cookies } & \multirow{2}{*}{$\begin{array}{c}\text { Header } \\
\text { (Amount of additive) } \\
\end{array}$} & $\mathrm{L}^{*}$ & $\mathrm{a}^{*}$ & $b^{*}$ \\
\hline & & \multicolumn{3}{|c|}{ NBS units } \\
\hline Wheat flour & & $68.29 \pm 0.7 \mathrm{e}$ & $7.08 \pm 0.1 \mathrm{a}$ & $34.73 \pm 0.4 \mathrm{~d}$ \\
\hline \multirow[t]{3}{*}{ Raspberry pomace flour } & $10 \%$ & $44.75 \pm 0.4 \mathrm{c}$ & $7.08 \pm 0.1 \mathrm{a}$ & $24.39 \pm 0.2 c$ \\
\hline & $15 \%$ & $39.42 \pm 0.3 \mathrm{a}$ & $13.18 \pm 0.2 \mathrm{c}$ & $22.43 \pm 0.3 b$ \\
\hline & $20 \%$ & $42.33 \pm 0.4 b$ & $11.19 \pm 0.3 b$ & $20.12 \pm 0.4 \mathrm{a}$ \\
\hline Red currant pomace flour & $10 \%$ & $49.33 \pm 0.4 \mathrm{~d}$ & $9.08 \pm 0.2 b$ & $23.81 \pm 0.3 b$ \\
\hline \multirow[t]{3}{*}{ Strawberry pomace flour } & $10 \%$ & $41.22 \pm 0.4 \mathrm{~b}$ & $13.09 \pm 0.1 \mathrm{c}$ & $26.88 \pm 0.4 \mathrm{e}$ \\
\hline & $15 \%$ & $48.76 \pm 0.3 \mathrm{~d}$ & $11.16 \pm 0.3 \mathrm{~b}$ & $23.64 \pm 0.3 \mathrm{~b}$ \\
\hline & $20 \%$ & $37.35 \pm 0.2 \mathrm{a}$ & $11.56 \pm 0.2 \mathrm{~b}$ & $21.36 \pm 0.2 \mathrm{a}$ \\
\hline
\end{tabular}

$\mathrm{L}^{*}$ - brightness ( $\mathrm{L}^{*}=0$ means black, $\mathrm{L}^{*}=100$ means white), $\mathrm{a}^{*}$ - (red/green), $\mathrm{b}^{*}$ - (yellow/blue), NBS units by CIE lab scale(colour-difference unit). Different letters above the column indicate significant differences between the mean values $(\mathrm{p} \leq 0.05)$ (Mean $\pm \mathrm{SD})$.

Hardness is an important sensory characteristic of cookies. After evaluating the hardness of the dough, it was found that the hardest dough was the one with $15 \%$ red currant pomace $(2.20 \mathrm{~N})$, and the softest was the one with $10 \%$ raspberry pomace flour $(0.64 \mathrm{~N})$. Significant differences were observed in the dough with red currant pomace. Strawberry pomace flour, regardless of quantity, did not affect the hardness of the dough, which was not significantly different from the $15 \%$ and $20 \%$ additive of red currant flour (Table 7).

Biscuit hardness is an important physical parameter in the biscuit quality evaluation, which in turn affects the sensory attributes of biscuits. The hardest cookies were those with $10 \%$ raspberry pomace flour supplement $(36.09 \mathrm{~N})$, and the softest were those with $20 \%$ strawberry pomace flour supplement 
Table 7. The texture of cookies dough and cookies with berry pomace flour.

\begin{tabular}{|c|c|c|c|c|}
\hline \multirow{2}{*}{$\begin{array}{l}\text { Header } \\
\text { (Cookies) }\end{array}$} & \multirow{2}{*}{$\begin{array}{c}\text { Header } \\
\text { (Amount of additive) }\end{array}$} & \multirow{2}{*}{$\begin{array}{c}\text { Cookies dough } \\
\text { Hardness }(\mathrm{N})\end{array}$} & \multicolumn{2}{|c|}{ Cookies } \\
\hline & & & Hardness $(\mathrm{N})$ & Brittleness $(\mathrm{mm})$ \\
\hline Wheat flour & & $1.24 \pm 0.08 \mathrm{~d}$ & $30.59 \pm 0.5 g^{\star}$ & $7.55 \pm 0.09 \mathrm{~b}$ \\
\hline \multirow[t]{3}{*}{ Raspberry pomace flour } & $10 \%$ & $0.64 \pm 0.06 \mathrm{a}$ & $36.09 \pm 0.6 \mathrm{~h}$ & $8.35 \pm 0.1 \mathrm{c}$ \\
\hline & $15 \%$ & $0.86 \pm 0.07 \mathrm{~b}$ & $27.17 \pm 0.4 \mathrm{f}$ & $7.69 \pm 0.06 \mathrm{~b}$ \\
\hline & $20 \%$ & $0.78 \pm 0.08 \mathrm{~b}$ & $22.11 \pm 0.3 \mathrm{~d}$ & $8.51 \pm 0.07 c$ \\
\hline \multirow[t]{3}{*}{ Red currant pomace flour } & $10 \%$ & $0.97 \pm 0.06 \mathrm{c}$ & $12.60 \pm 0.1 \mathrm{~b}$ & $7.14 \pm 0.06 \mathrm{a}$ \\
\hline & $15 \%$ & $2.20 \pm 0.2 \mathrm{f}$ & $15.49 \pm 0.3 b$ & $7.30 \pm 0.06 \mathrm{a}$ \\
\hline & $20 \%$ & $1.51 \pm 0.08 \mathrm{e}$ & $18.16 \pm 0.3 c$ & $7.07 \pm 0.06 \mathrm{a}$ \\
\hline \multirow[t]{3}{*}{ Strawberry pomace flour } & $10 \%$ & $1.53 \pm 0.06 \mathrm{e}$ & $22.25 \pm 0.2 \mathrm{~d}$ & $7.44 \pm 0.05 \mathrm{a}$ \\
\hline & $15 \%$ & $1.58 \pm 0.08 \mathrm{e}$ & $11.88 \pm 0.1 \mathrm{~b}$ & $7.32 \pm 0.04 \mathrm{a}$ \\
\hline & $20 \%$ & $1.57 \pm 0.06 \mathrm{e}$ & $6.43 \pm 0.06 \mathrm{a}$ & $7.03 \pm 0.06 \mathrm{a}$ \\
\hline
\end{tabular}

Different letters above the column indicate significant differences between the mean values ( $\mathrm{p} \leq 0.05)$ (Mean \pm SD). Units are standardised in the Rockwell method (International Organization for Standardization, 2015b) N- maximum force opposed to fracture.

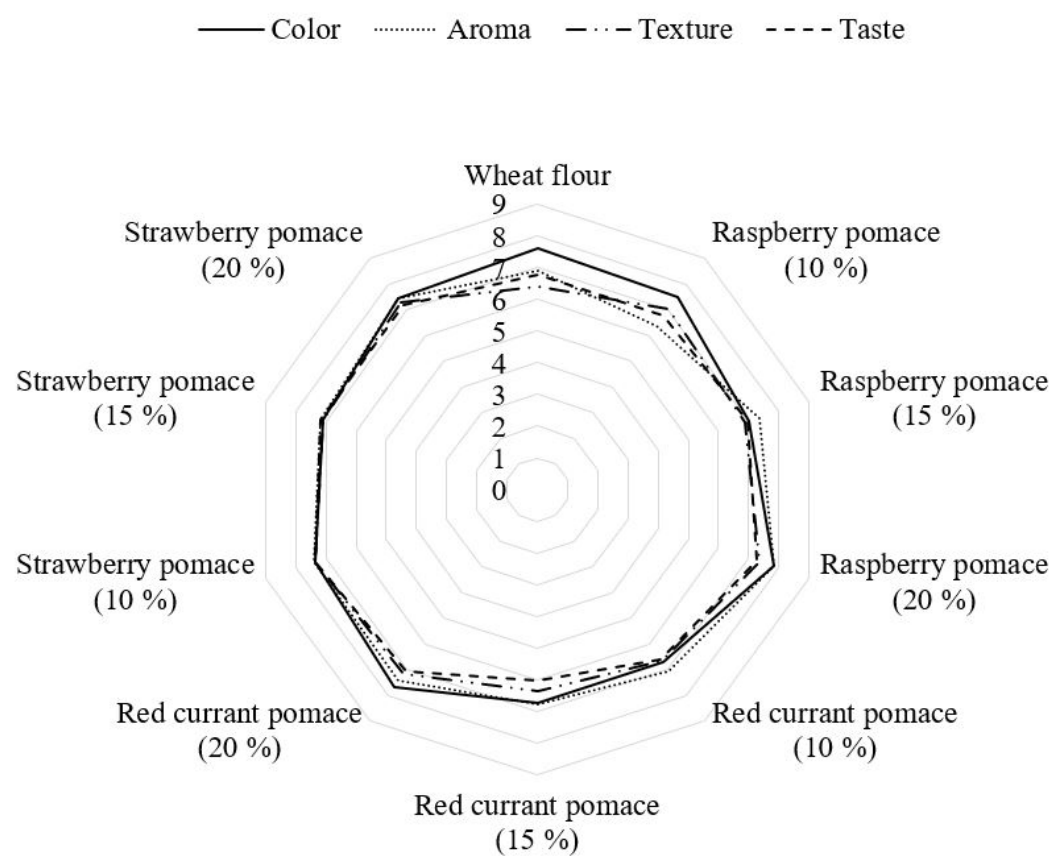

Figure 3. The influence of adding berry pomace supplement on sensory qualities of cookies. The colour, aroma, texture and taste of the cookie samples were evaluated by a 9 point hedonic scale, where $1=$ extremely dislike; 2 = dislike very much; $3=$ dislike moderately; 4 = dislike slightly; 5 = neither like or dislike; 6 = like slightly; 7 = like moderately; $8=$ like very much; and $9=$ extremely like, evaluators did not choose 9 point, so scale range just for 8 point.

$(6.43 \mathrm{~N})$. The high concentration of dietary fibre in strawberry pomace flour may have retained the moisture in the cookies, thus yielding softer cookies. It has been observed that the greater the concentration of raspberry and strawberry pomace, the softer the cookies, but with currant pomace, the opposite happened; the higher the pomace concentration, the harder the cookies. While evaluating the fragility of the experimental cookies, it was found that cookies with $20 \%$ strawberry pomace flour additives were the least brittle $(7.03 \mathrm{~mm})$, and the most fragile were those with $20 \%$ raspberry pomace flour additives (Table 7 ).

According Felisberto et al. (2019) wheat flour cookies without additives is $36.27(\mathrm{~N})$ hardness this is similar to our results $(30.59 \mathrm{~N})$ (Table 7$)$.
Correlation analysis was used to study how dietary fibre affects the qualities of cookies. The analytical results showed that cookie hardness was significantly correlated with dietary fibre content $(r=0.90-0.99)$ in all the cookies with berry pomace flour supplement.

According to Agu et al. (2007), cookies are described as small, brittle sweet and greasy dough confectionery made from unfermented dough. The cookies were evaluated for their colour, aroma, texture and taste. Analysis of the organoleptic properties of the cookies determined that cookies with $15 \%$ red currant flour additive obtained minimum scores of $6.72,6.78$, 6.33 and 6 for the colour, aroma, texture and taste, respectively. The highest score was for biscuits with $20 \%$ strawberry pomace 
flavour supplement: colour -7.83 points, aroma -7.83 points, and texture -7.33 points. The evaluators considered that the most delicious cookies were the ones with $10 \%$ raspberries pomace flour additive, with a total taste rating of 7.33. The cookies with the most attractive colour were those with $20 \%$ red currant and strawberry pomace flour additives. The cookies that received the highest score after the sensory evaluation were those with $20 \%$ strawberry pomace, and the lowest were those with 15\% red currant pomace flour additives (Figure 3).

\section{Conclusions}

This study showed that berry pomace could be a proper source of dietary fibre for cookie enrichment. The highest amount of fat and fibre was found in raspberry pomace. The red currant pomace was determined as the most acidic, and with the highest amount of protein. Significantly the highest amount of neutral detergent fibre (NDF), acid detergent fibre (ADF) and insoluble fibre fraction of modified acid detergent solution (MADF) was found in raspberry pomace, and the lowest was found in strawberry pomace. The addition of raspberry pomace to wheat dough led the amount of fibre in the cookies to be twice as high as that in wheat dough cookies. As the concentration of raspberry and strawberry pomace increased, the cookies became softer. Cookies with pomace were darker, more reddish and less yellow. The darkest ones were the cookies with $20 \%$ strawberry pomace. According to the results of the sensory evaluation, cookies with $20 \%$ strawberry pomace had the highest scores from the panellists.

\section{References}

Agu, H. O., Ayo, J. A., Paul, A. M., \& Folorunsho, F. (2007). Quality characteristics of biscuits made from wheat and African breadfruit (Treculia afriana). Nigerian Food Journal, 25, 19-27.

American Association of Cereal Chemists - AACC. (2000). Approved methods of the AACC (10th ed.). St. Paul: AACC International.

Angulo, J., Mahecha, L., Yepes, S. A., Yepes, A. M., Bustamante, G., Jaramillo, H., Valencia, E., Villamil, T., \& Gallo, J. (2012). Nutritional evaluation of fruit and vegetable waste as feedstuff for diets of lactating Holstein cows. Journal of Environmental Management, 95(Suppl.), S210-S214. http://dx.doi.org/10.1016/j.jenvman.2011.06.050. PMid:21784573.

Ayala-Zavala, J. F., Vega-Vega, V., Rosas-Domínguez, C., PalafoxCarlos, H., Villa-Rodriguez, J. A., Siddiqui, M. W., Dávila-Aviña, J. E., \& González-Aguilar, G. A. (2011). Agro - industrial potential of exotic fruit by products as a source of food additives. Food Research International, 44(7), 1866-1874. http://dx.doi.org/10.1016/j. foodres.2011.02.021.

Brites, L. T. G. F., Ortolan, F., Silva, D. W., Bueno, F. R., Rocha, T. S., Chang, Y. K., \& Steel, C. J. (2019). Gluten-free cookies elaborated with buckwheat flour, millet flour and chia seeds. Food Science and Technology, 39(2), 458-466. http://dx.doi.org/10.1590/fst.30416.

Brodowska, A. J. (2017). Raspberry pomace - composition, properties and application. European Journal of Biological Research, 7, 86-96.

Butkutè, B., Lemežienè, N., Cesevičienè, J., Liatukas, Ž., \& Dabkevičienè, G. (2013). Carbohydrate and lignin partitioning in switchgrass (Panicum virgatum $\mathrm{L}$.) biomass as a bioenergy feedstock. Zemdirbyste-Agriculture, 100(3), 251-260. http://dx.doi.org/10.13080/z-a.2013.100.032.
Chauhan, A., Saxena, D. C., \& Singh, S. (2016). Physical, textural, and sensory characteristics of wheat and amaranth flour blend cookies. Cogent Food \& Agriculture, 2(1), 1125773. http://dx.doi.org/10.108 0/23311932.2015.1125773.

Djilas, S., Canadanovic-Brunet, J., \& Cetkovic, G. (2009). By - products of fruits processing as a source of phytochemicals. Chemical Industry \& Chemical Engineering Quarterly, 15(4), 191-202. http://dx.doi. org/10.2298/CICEQ0904191D.

Faithfull, N. T. (2002). Methods in agricultural ghemical analysis: a practical handbook (pp. 124-125). UK: CABI Publishing is a division of CAB International.

Felisberto, M. H. F., Miyake, P. S. E., Beraldo, A. L., Fukushima, A. R., Leoni, L. A. B., \& Clerici, M. T. P. S. (2019). Effect of the addition of young bamboo culm flour as a sugar and/or fat substitute in cookie formulations. Food Science and Technology, 39(4), 867-874. http:// dx.doi.org/10.1590/fst.12418.

Fotschki, B., Juśkiewicz, J., Jurgoński, A., Kosmala, M., Milala, J., Zduńczyk, Z., \& Markowski, J. (2019). Grinding levels of raspberry pomace affect intestinal microbial activity, lipid and glucose metabolism in Wistar rats. Food Research International, 120, 399-406. http://dx.doi. org/10.1016/j.foodres.2019.03.014. PMid:31000255.

Górecka, D., Korczak, J., Balcerowski, E., \& Decyk, K. (2002). Sorption of bile acids and cholesterol by dietary fiber of carrots, cabbage and apples. Food Science and Technology, 5(2), 2.

Górecka, D., Pachołek, B., Dziedzic, K., \& Górecka, M. (2010). Raspberry pomace as a potential fiber source for cookies enrichment. Acta Scientiarum Polonorum. Technologia Alimentaria, 9(4), 451-462.

International Organization for Standardization - ISO. (1998). ISO 751. Geneva: ISO.

International Organization for Standardization - ISO. (2002). ISO 5984. Geneva: ISO.

International Organization for Standardization - ISO. (2008). ISO 13906. Geneva: ISO.

International Organization for Standardization - ISO. (2013). ISO 20483. Geneva: ISO.

International Organization for Standardization - ISO. (2015a). ISO 11085. Geneva: ISO.

International Organization for Standardization - ISO. (2015b). ISO 6508-1. Geneva: ISO.

Jones, D. I. H., \& Moseley, G. (1993). Laboratory methods for estimating nutritive quality. In A. Davies, R. D. Baker, S. A. Grant \& A. S. Laidlaw (Eds.), Sward measurement handbook (2nd ed., pp. 265-283). Reino Unido: British Grassland Society.

Jurgonski, A., Juskiewicz, J., Sójka, M., \& Karlinska, E. (2016). Dietinduced disorders in rats are more efficiently attenuated by initial rather than delayed supplementation with polyphenol-rich berry fibres. Journal of Functional Foods, 22, 556-564. http://dx.doi. org/10.1016/j.jff.2016.02.018.

Kosmala, M., Zduńczyk, Z., Kołodziejczyk, K., Klimczak, E., Juśkiewicz, J., \& Zduńczyk, P. (2014). Chemical composition of polyphenols extracted from strawberry pomace and their effect on physiological properties of diets supplemented with different types of diatary fibre ai rats. European Journal of Nutrition, 53(2), 521-532. http://dx.doi. org/10.1007/s00394-013-0557-z. PMid:23846557.

Kostecka-Gugała, A., Ledwożyw-Smoleń, I., Augustynowicz, J., Wyżgolik, G., Kruczek, M., \& Kaszycki, P. (2015). Antioxidant properties of fruits of raspberry and blackberry grown in central Europe. Open Chemistry, 13(1), 1313-1325. http://dx.doi.org/10.1515/chem2015-0143. 
Kryževičiūte, N., Kraujalis, P., \& Venskutonis, P. R. (2016). Optimization of high pressure extraction processes for the separation of raspberry pomace into lipophilic and hydrophilic fractions. The Journal of Supercritical Fluids, 108, 61-68. http://dx.doi.org/10.1016/j. supflu.2015.10.025.

Leroy, B. L. M. M., Bommele, L., Reheul, D., Moens, M., \& De Neve, S. (2007). The application of vegetable, fruit and garden waste (VFG) compost in addition to cattle slurry in a silage maize monoculture: effects on soil fauna and yield. European Journal of Soil Biology, 43(2), 91-100. http://dx.doi.org/10.1016/j.ejsobi.2006.10.005.

McDougall, N. R., \& Beames, R. M. (1994). Composition of raspberry pomace and it's nutritive value for monogastric animals. Animal Feed Science and Technology, 45(2), 139-148. http://dx.doi.org/10.1016/03778401(94)90022-1.

Mudgil, D., Barak, S., \& Khatkar, B. S. (2017). Cookie texture, spread ratio and sensory acceptability of cookies as a function of soluble dietary fiber, baking time and different water levels. LebensmittelWissenschaft + Technologie, 80, 537-542. http://dx.doi.org/10.1016/j. lwt.2017.03.009.

Naknaen, P., Itthisoponkul, T., Sondee, A., \& Angsombat, N. (2016). Utilization of watermelon rind waste as a potencial source of dietary fiber to improve health promoting properties and reduce glycemic index for cookie making. Food Science and Biotechnology, 25(2), 415424. http://dx.doi.org/10.1007/s10068-016-0057-z. PMid:30263285.

O'Shea, N., Arendt, E. K., \& Gallagher, E. (2012). Dietary fibre and phytochemical characteristics of fruit and vegetable by-products and their recent applications as novel ingredients in food products. Innovative Food Science \& Emerging Technologies, 16, 1-10. http:// dx.doi.org/10.1016/j.ifset.2012.06.002.

Peryam, D. R., \& Pilgrim, F. J. (1957). Hedonic scale method of measuring food preferences. Food Technology, 11, 9-14.

Rodríguez, R., Jiménez, A., Fernández-Bolaños, J., Guillén, R., \& Heredia, A. (2006). Dietary fibre from vegetable products as source of functional ingridients. Trends in Food Science \& Technology, 17(1), 3-15. http://dx.doi.org/10.1016/j.tifs.2005.10.002.
Sanchez-Rivera, M. M., Bello-Pérez, L. A., Tovar, J., Martinez, M. M., \& Agama-Acevedo, E. (2019). Esterified plantain flour for the production of cookies rich in indigestible carbohydrates. Food Chemistry, 292, 1-5. http://dx.doi.org/10.1016/j.foodchem.2019.04.007. PMid:31054650.

Tagliani, C., Perez, C., Curutchet, A., Arcia, P., \& Cozzano, S. (2019). Blueberry pomace, valorization of an industry by-product source of fibre with antioxidant capacity. Food Sci. Technol, 39(3), 644-651. http://dx.doi.org/10.1590/fst.00318.

Telrandhe, U. B., Kurmi, R., Uplanchiwar, V., Mansoori, M. H., Raj, V. J., \& Jain, K. (2012). Nutraceuticals - a phenomenal resource in modern medicine. International Journal of Universal Pharmacy and Life Sciences, 2(1), 179-195.

Van Soest, P. J., Robertson, J. B., \& Lewis, B. A. (1991). Methods for dietary fiber, neutral detergent fiber, and nonstarch polysaccharides in relation to animal nutrition. Journal of Dairy Science, 74(10), 3583-3597. http://dx.doi.org/10.3168/jds.S0022-0302(91)78551-2. PMid:1660498.

Verdú, S., Barat, J. M., \& Grau, R. (2019). Laser backscattering imaging as a non-destructive quality control technique for solid food matrices: Modelling the fibre enrichment effects on the physico-chemical and sensory properties of biscuits. Food Control, 100, 278-286. http:// dx.doi.org/10.1016/j.foodcont.2019.02.004.

Yemm, E. W., \& Willis, A. J. (1954). The estimation of carbohydrates in plant extracts by anthrone. The Biochemical Journal, 57(3), 508-514. http://dx.doi.org/10.1042/bj0570508. PMid:13181867.

Žilić, S., Kocadağlı, T., Vančetović, J., \& Gökmen, V. (2016). Effects of baking conditions and dough formulations on phenolic compound stability, antioxidant capacity and color of cookies made from anthocyanin-rich corn flour. Lebensmittel-Wissenschaft + Technologie, 65, 597-603. http://dx.doi.org/10.1016/j.lwt.2015.08.057.

Zucco, F., Borsuk, Y., \& Arntfield, S. D. (2011). Physical and nutritional evaluation of wheat cookies supplemented with pulseflours of different particle sizes. Lebensmittel-Wissenschaft + Technologie, 44(10), 2070-2076. http://dx.doi.org/10.1016/j.lwt.2011.06.007. 